Thematic Section: Research into New Technologies. Subsection: Physical Organic Chemistry.

Thematic course: Solid state nanoreactor. Part VIII.

\title{
Encapsulation of isoquinoline in a polymer nanocontainer based on the $\mathrm{CU}-2-4$ sulfocationite
}

\author{
(C) Heinrich N. Altshuler, ${ }^{*}$ Galina Yu. Shkurenko, ${ }^{+}$and Sergey Yu. Lyrschikov \\ Institute of Coal Chemistry and Material Science. Federal Research Center of Coal and Coal Chemistry. \\ Siberian Branch of Russian Academy of Sciences. Sovetsky pr., 18. Kemerovo, 650000. Russia. \\ Phone: +7 (384-2) 36-88-04. E-mail: altshulerh@gmail.com
}

Keywords: encapsulation, isoquinoline, CU-2-4 sulphocationite.

*Supervising author; ${ }^{+}$Corresponding author

\begin{abstract}
The possibility of the encapsulation of isoquinoline in the nanocontainer on the matrix of the sulfonated copolymer based on styrene and divinylbenzene (CU-2-4 sulfocationite) has been researched. The encapsulation of isoquinoline in the nanocontainer on polymer matrix was performed by ion-exchange sorption from aqueous solutions. CU-2-4 sulfocationite in hydrogen and isoquinoline forms was studied by NMR and Fourier IR spectroscopy. In the ${ }^{13} \mathrm{C}$ NMR spectra of solid-state samples of the CU-2-4 cation exchanger in the isoquinoline form is observed additional resonance absorption band of ${ }^{13} \mathrm{C}$ in the range of chemical shift $136 \mathrm{ppm}$, corresponding to the nodal carbon atom of the pyridine ring. The IR spectrum of the polymer containing the encapsulated isoquinoline be observed bands characteristic for skeletal vibrations in the area of isoquinoline fingerprints $\left(1300-1600 \mathrm{~cm}^{-1}\right)$ and the band of $938 \mathrm{~cm}^{-1}$ that corresponds to the deformation vibrations of the $\mathrm{CH}$-group of pyridine ring, which is not in the spectrum of the $\mathrm{H}$-form sulfocationite. The ion-exchange capacity of the nanocontainer based on CU-2-4 sulfocationite for isoquinoline was $5.5 \mathrm{meq} / \mathrm{g}$. This corresponds to the content of ionogenic groups in the polymer. The dynamic ion-exchange capacity of sulfonated CU-2-4 cation exchanger during encapsulation of isoquinoline coincides with the ion-exchange capacity of sulfonated cation exchanger upon the release of isoquinoline from the polymer nanocontainer. The content of immobilized isoquinoline in the nanocontainer on the CU-2-4 matrix reaches $71 \%$ by weight of the polymer. It is shown that isoquinoline is encapsulated and desorbed with the solution of hydrochloric acid at the same rate. Encapsulated isoquinoline is completely released from the polymer by desorption with the aqueous hydrochloric acid solution. The half-life during sorption and desorption (release) of isoquinoline is approximately 400 seconds. It is shown that the encapsulated isoquinoline to be completely released from the polymer by desorption with an aqueous hydrochloric acid solution. The kinetics of the encapsulation and release of isoquinoline from the nanocontainer based on CU-24 sulfocationite is determined by its diffusion in the polymer phase.
\end{abstract}

\section{References}

[1] R.C. Dutta. Drug carriers in pharmaceutical design: promises and progress. Current Pharmaceutical Design. 2007. Vol.13. P.761-769.

[2] S. Freiberg, X. Zhu. Polymer microspheres for controlled drug release. Int. J. Pharm. 2004. Vol.282. P.1-18.

[3] Шкуренко Г.Ю., Лырщиков С.Ю., Горлов А.А., Альтшулер Г.Н., Альтшулер О.Г. Иммобилизация бензакаина в полимерных наноконтейнерах. Моделирование фармакокинетики. Хим.-фарм. ж. 2018. T.52. №5. C.46-48. DOI: 10.30906/0023-1134-2018-52-5-46-48

[4] H.N. Altshuler, G.Yu. Shkurenko, S.Yu. Lyrschikov, A.A. Gorlov, and O.H. Altshuler. Solid nanoreactor. Part 5. Polymer nanocontainers for benzocaine. Butlerov Communications. 2015. Vol.44. No.11. P.69-72. DOI: 10.37952/ROI-jbc-01/15-44-11-69

[5] E.V. Ostapova, G.Yu. Shkurenko, S.Yu. Lyrschikov, and H.N. Altshuler. Sulphonated network polymers as containers for bioactive substances. Butlerov Communications. 2016. Vol.48. No.10. P.37-42. DOI: 10.37952/ROI-jbc-01/16-48-10-37

[6] H.N. Altshuler, G.Yu. Shkurenko, N.V. Malyshenko, and S.Yu. Lyrschikov. Immobilization of pyridinecarboxylic acids in a polymer nanocontainer based on the AB-17-8 strongly basic anion exchanger. Butlerov Communications. 2018. Vol.54. No.4. P.82-87. DOI: 10.37952/ROI-jbc-01/18-54-4-82

[7] G.N. Altshuler, G.Yu. Shkurenko, A.A. Gorlov. Kinetics of the reduction of $p$-nitrobenzoic acid esters in

Kazan. The Republic of Tatarstan. Russia. (C)Butlerov Communications. 2020. Vol.61. No.2. 

nanoreactors on the basis of sulfonated polymers. Russian Journal of Physical Chemistry A. 2015. Vol.89. P.372-375. https://doi.org/10.1134/S0036024415030024

[8] H.N. Altshuler, G.Yu. Shkurenko, E.V. Ostapova, and O.H. Altshuler. Cation exchange kinetics of pyridinecarboxylic acids. Russian Chemical Bulletin, International Edition. 2017. Vol.66. No.7. P.11771182. https://doi.org/10.1007/s11172-017-1869-6

[9] H.N. Altshuler, E.V. Ostapova, N.V. Malyshenko, and O.H. Altshuler. Sorption of nicotinic and isonicotinic acids by the strongly basic anion exchanger AB-17-8. Russian Chemical Bulletin. 2017. Vol.66. P.1854-1859. https://doi.org/10.1007/s11172-017-1957-7

[10] H.N. Altshuler, G.Yu. Shkurenko, O.H. Altshuler. Anion exchange kinetics with participation of cinchomeronic and dipicolinic acids. Russian Chemical Bulletin. 2018. Vol.67. No.10. P.1927-1930. https://doi.org/10.1007/s11172-018-2309-y

[11] M.D. Mashkovsky. Medicines. Moscow: New wave. 2002. Vol.1. 608p. (russian)

[12] G.N. Altshuler, Y.S. Porodnova, Y.A Makarov. Application of ionites to the production of pharmaceutical products. Pharmaceutical Chemistry Journal. 1969. Vol.3. P.404-406. https://doi.org/10.1007/BF00761047

[13] O.N. Fedoseeva, E.P. Cherneva, and N.N. Tunitskii. Zh. Fiz. Khim. 1959. Vol.33. No.4. P.936-942. (russian)

[14] E. Pretsch, P. Buhlmann, and C. Affolter. Structure Determination of Organic Compounds. Berlin, New York: Springer. 2000.

[15] L. Bellamy. Infrared spectra of complex molecules. trans. from English under the editorship of Yu.A. Pentin. Moscow: Foreign literature. 1963. 590p. (russian)

[16] K. Nakanishi. Infrared spectra and the structure of organic compounds. Moscow: World. 1965. 216p. (russian)

[17] L.K. Shataeva, N.N. Kuznetsova, G.E. Elkin. Carboxyl ion exchangers in biology. Leningrad: Science. 1979. (russian) 